\title{
CONGENITAL FISTULA OF THE LACRIMAL GLAND*
}

\author{
BY \\ F. J. DAMATO \\ Paula, Malta
}

THE CASE reported below is of interest because of its rarity and because of the unusual position of the fistula. In all the ten cases so far recorded in the literature, the opening is situated in the outer part of the upper lid just above the level of the tarsal plate. In one case-an abnormal lacrimal ductule reported by Ling (1926) - the aperture opens on to the skin lateral to the external canthus, which is deformed, because of failure of approximation of the lateral extremities of the lids.

\section{Case Report}

A male infant aged 3 months was brought by his mother to hospital for examination, because she noticed tears coming out from the side of the right eye when the child cried or yawned.

On examination, a small orifice could be seen in the skin $5 \mathrm{~mm}$. lateral to the external canthus (Figs 1 and 2).
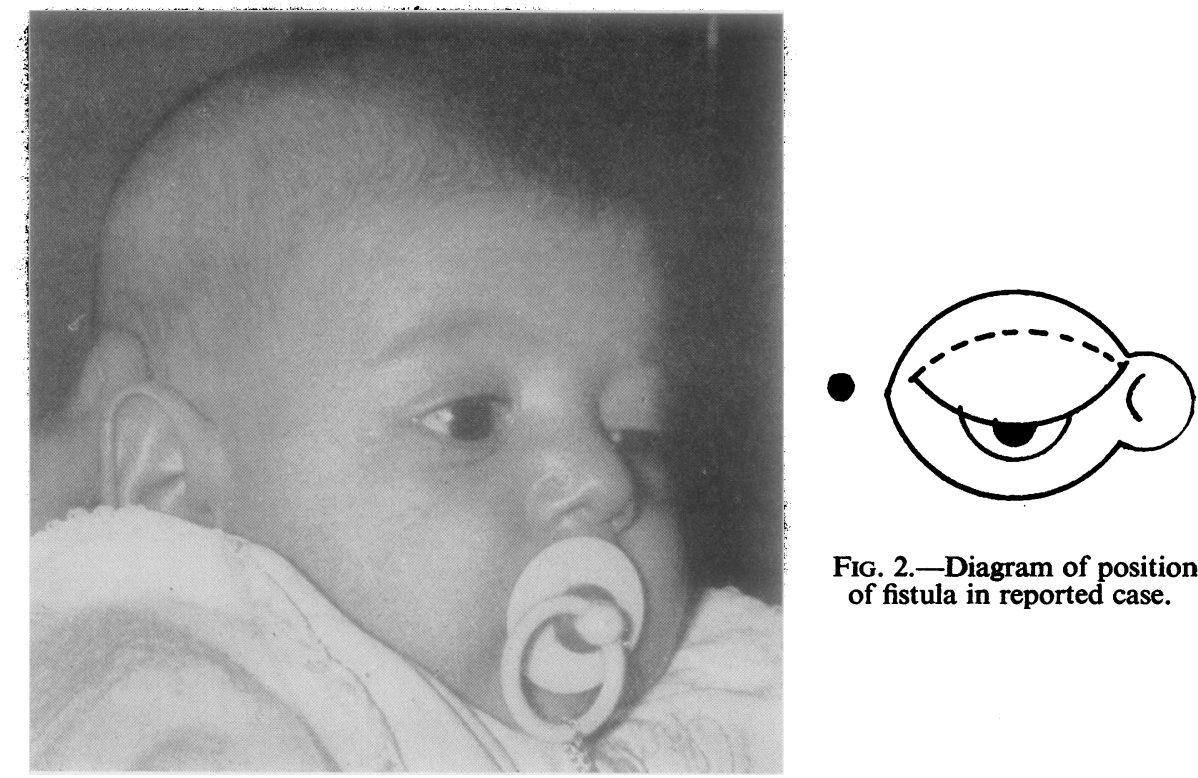

Fig. 2.-Diagram of position of fistula in reported case.

FIG. 1.-External appearance of orifice in the skin beside the right eye.

* Received for publication April 9, 1956. 
The external canthus was normally developed. The opening was round, about $1 \mathrm{~mm}$. in diameter and there were no lash-like hairs on the skin around it. No nodular enlargements could be felt near or around the opening. There was no sign that palpation of the region was followed by pain. Transparent fluid could be seen discharging from the orifice on all occasions when tears flowed from the eye (Fig. 1). The flow continued so long as tears kept coming out of the eye and was increased by ordinary stimuli which augment lacrimation, such as cold wind or pain. So far, there was no evidence of excoriation or maceration of the skin around the orifice. A small probe could be passed for about $6 \mathrm{~mm}$. in the direction of the lateral conjunctival fornix.

Radiographical examination after injection

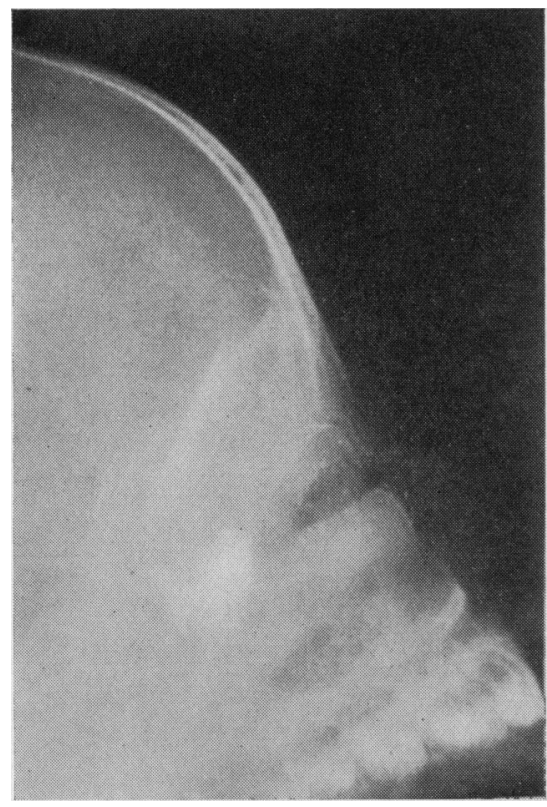

FIG. 3.-Radiograph of skull showing connexion of fistula with glandular tissue. of Lipiodol into the orifice showed that the fistula was in direct connextion with glandular tissue. The pool of liquid was localized to the lateral canthus region and had no relation with the lateral conjunctival fornix (Fig. 3).

\section{Comment}

It is of interest to consider the position of the fistula in some recorded cases. In a case described by Schornstein (1935) the orifice of the fistula was situated in the mid-line of the upper lid just above the tarsal plate (Fig. 4).

In the case reported by Terlinck (1910), the fistula was situated lateral to the mid-line above the border of the tarsal plate (Fig. 5).

In the case reported by Ling (1926), the lateral extremities of the upper and lower lids did not meet but merged into a semilunar fold of skin and remained separated by a space $5 \mathrm{~mm}$. wide. An anomalous lacrimal ductule opened by an oblique slit-like orifice immediately external to the malformed canthus (Fig 6).

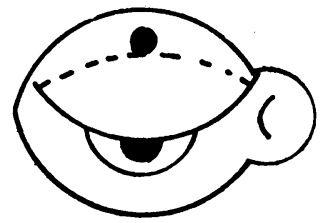

Fig. 4.-Position of fistula in case described by Schornstein (1935).

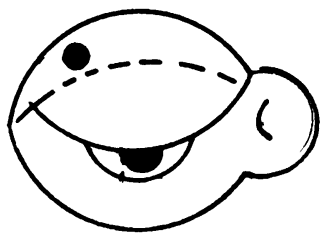

Fig. 5.-Position of fistula in case described by Terlinck (1910).

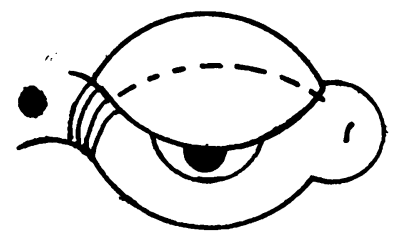

FIG. 6.-Position of fistula in case described by Ling (1926). 
According to Duke-Elder (1952), most of these fistulae may be formed by an invagination of the surface epithelium at a higher level than usual before the lid folds have formed, so that the ductule originates from the cutaneous epithelium.

Cange and Duboucher (1931) suggested that they may represent ectodermic inclusions in the embryonic folding around the eye. Schornstein (1936) thought that the fistula might be due to the rupture of a congenital cyst.

It is quite possible that the lacrimal fistula described in the case reported above is the opening of the ductule of one of the outlying accessory lacrimal glands described by Krause (1854). These are microscopic acinotubular glands scattered along the conjunctival fornix especially laterally (Whitnall, 1932).

\section{Summary}

A case is described of a fistula of the lacrimal gland opening laterally to the external canthus which was normally developed.

It is suggested that the fistula might be the opening of the ductule of one of the accessory lacrimal glands of Krause.

\section{REFERENCES}

Cange, A., and Duboucher, J. (1931). Arch. Ophtal., 48, 161. (Quoted from Duke-Elder, 1952.)

DUKE-ELDER, S. (1952). " "Text-book of Ophthalmology", vol. 5, p. 4695. Kimpton, London.

KRAUSE, W. (1854). Z. rat. Med., n.s.iv., p. 33 (Quoted from Whitnall, 1932).

LING, W. P. (1926). Amer. J. Ophthal., 9, 1.

SCHORNSteIN, T. (1935). Arch. Augenheilk., 109, 86. (Quoted from Duke-Elder, 1952.)

TerLINCK, H. (1910). Z. Augenheilk., 24, 522 . (Quoted from Duke-Elder, 1952.)

Whitnall, S. E. (1932). "The Anatomy of the Human Orbit", 2nd ed., p. 200. Oxford University Press, London. 